\title{
Early (3700 Ma) Archaean rocks of the Isua supracrustal belt and adjacent gneisses
}

\author{
Allen P. Nutman, David Bridgwater, Erich Dimroth, Robin C. O. Gill and \\ Minik Rosing
}

\begin{abstract}
A coherent stratigraphy is recognised in the highly deformed, amphibolite facies early Archaean Isua supracrustal belt. The supracrustal belt consists of layered rocks (in which sedimentary structures are locally preserved), ultramafic rocks and units of garbenschiefer (a massive $\mathrm{Mg}$-Al rich, leucoamphibolite). The layered supracrustal rocks form two sequences, which are separated from each other tectonically. When folding is taken into account, these sequences are now less than $200 \mathrm{~m}$ thick. Sequence A forms most of the belt. In it there is a transition upwards from predominantly layered amphibolites with banded iron formation horizons to calc-silicate rocks, carbonates and layered felsic metasediments. Sequence B is restricted to the western edge of the eastern part of the supracrustal belt. It changes upwards from predominantly layered felsic metasediments to ferromagnesian mica schists. The supracrustal belt is regarded as a thin fragment from a thicker, more extensive volcanosedimentary pile.

The early Archaean gneisses adjacent to the supracrustal belt consist of early multiphase tonalites which were first intruded by mafic dioritic dykes and then by granitic sheets. The granitic sheets were originally horizontal to gently inclined and form up to 40 per cent of the gneiss complex. Interdigitation of supracrustal rocks and gneisses in the Isukasia area is due to both the style of intrusion of the gneisses and to tectonic intercalation.

Archaean basic dykes that cut the supracrustal belt and adjacent gneisses are of several generations. Within and south of the supracrustal belt they are generally strongly deformed and have been recrystallised under amphibolite facies conditions; but in the north of the area they are generally better preserved. The dykes cut across several generations of structures in the supracrustal belt and the adjacent gneisses.
\end{abstract}

\section{Introduction}

The Isua supracrustal belt (Allaart, 1976; Bridgwater et al., 1976; fig. 1) is at least 3750 Ma old (Moorbath et al., 1975; Baadsgaard, 1976; Hamilton et al., 1978). It is enveloped by a multiphase banded orthogneiss complex which gives a regional Rb-Sr whole-rock age of $c$. $3600 \mathrm{Ma}$. Tonalitic and granodioritic veins intruding the supracrustal belt yield data points on the $3600 \mathrm{Ma}$ isochron (Moorbath et al., 1977). The isotopic data and field relations support the contention (Bridgwater \& McGregor, 1974) that the Isua gneisses and Isua supracrustal rocks are the broad chronological equivalents of the Amîtsoq gneisses and Akilia association rocks, respectively (McGregor, 1973; McGregor \& Mason, 1977).

The 1980 field season was the start of a follow-up programme concentrating on geological problems whose solution was considered central to the correct interpretation of specialised 


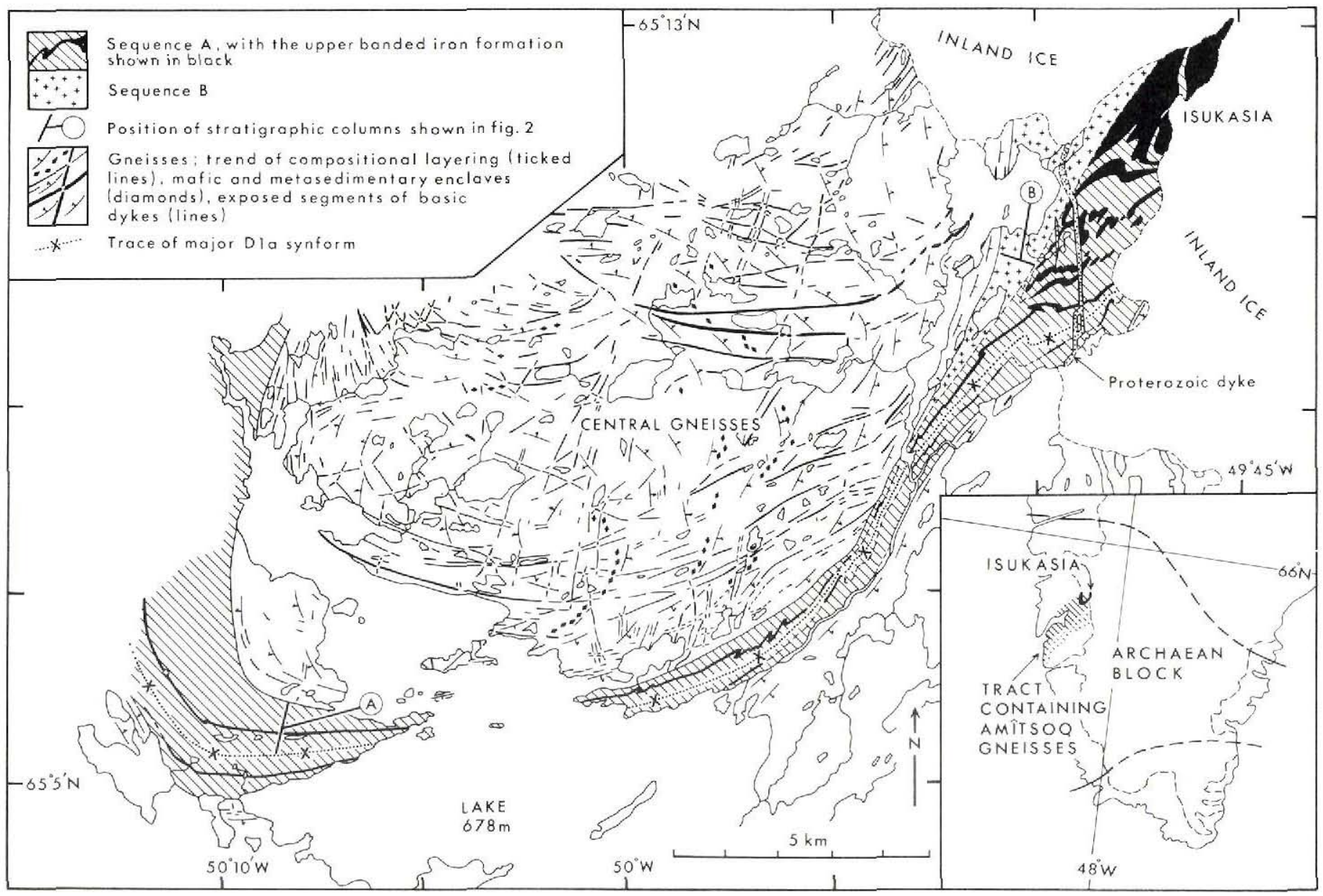

Fig. 1. Principal features of the Isukasia area visited in 1980. 
geochemical and isotopic investigations of the rocks of the Isukasia* area (Bridgwater et al., 1979). The objectives of this programme may be summarised as follows:

(1) Stratigraphic and lithological studies on the supracrustal rocks, with the ultimate aim of determining their depositional environment.

(2) Mapping and eventual stratigraphic sub-division of the quartzo-feldspathic orthogeneisses enveloping the supracrustal rocks.

(3) Studies on the intrusive chronology and possible lithological variations among the basic dykes that cut the Isua supracrustal rocks and surrounding gneisses.

(4) Structural studies on the supracrustal rocks and surrounding gneisses, both as an important part in the determination of their protoliths and as a key to correlating events in the Isukasia area with those of the Godthåbsfjord area.

Results of these studies are incorporated in Table 1.

\section{Table 1. Geological events}

11 Youngest. Thermal event (greenschist facies) and local emplacement of crustally derived granitic sheets, faulting.

c. $1600 \mathrm{Ma}$

10 Intrusion of basic dykes.

9 Deformation (D2-D4), rotaion or tightening of structures to give the supracrustal belt its arcuate shape. Metamorphism up to amphibolite facies and intrusion of pegmatitic gneiss sheets (particularly south of the supracrustal belt).

8 Intrusion of the Tarssartôq dykes.

7 Formation of non-cylindrical folds (D1c), resulting in an antiformal structure in the central gneisses.

6 Intrusion of thin grey sheets.

5 Intrusion of the white gneisses, with deformation (D1b) including tectonisation of grey gneiss - supracrustal belt contacts.

4 Intrusion of the Inaluk dykes.

3 Intrusion of the early thin grey sheets.

2 Intrusion of the grey gneisses; probably with isoclinal folding in the supracrustal rocks (D1a) and amphibolite facies metamorphism.

all or some in interval 3750 to $3500 \mathrm{Ma}$

pre-3750 Ma

Table compiled on the basis that all the gneisses are younger than the supracrustal rocks and all the Tarssartôq dykes are equivalent to the Ameralik dykes.

\footnotetext{
* 'Isukasia' refers to the same place as 'Isua' in previous literature on the Isua supracrustal belt. 'Isua' was changed to 'Isukasia' by the Greenlandic Place Names Commission in 1980.
} 


\section{Isua Supracrustal Rocks}

The Isua supracrustal belt is a multilayer complex with constituent units of contrasting rheological properties that has been subjected to several tectonometamorphic events (Table 1). Commonly, finite strain is large, but despite this the gross lithological layering and a number of regional sedimentary and igneous characters are preserved, which allow the subdivision of the supracrustal rocks into units that can be mapped throughout the belt. Thicknesses and mineral assemblages of individual units vary considerably along strike and on opposing limbs of folds because of rheological constrast between the units and because of the regional heterogeneity of strain and metamorphic grade. When these differences are allowed for, considerable progress can be made in identifying the protoliths and in drawing up a coherent stratigraphy for the whole belt. The correlation and following of units is hindered by the poor degree of exposure in large areas of the supracrustal belt. Locally, minor sedimentary structures such as graded layering are preserved which give facing directions, and these are invaluable for structural control and for more detailed assessment of the sedimentary environment.

The supracrustal belt consists of layered amphibolites, metacherts (quartzites with no evidence of detrital origin), banded iron formations, felsic rocks (some of detrital origin), banded calc-silicate rocks, ultramafic rocks (dunites, pyroxene-olivine rocks and their metamorphic equivalents) and the 'garbenschiefer unit', a massive chloritic leucoamphibolite schist with high $\mathrm{Mg}$ and $\mathrm{Al}$ contents.

The garbenschiefer and ultramafic units cut obliquely across the layered rocks of supracrustal origin. Furthermore, an ultramafic unit cuts the garbenschiefer to the west of lake $678 \mathrm{~m}$. It is clear that the ultramafic rocks were emplaced as intrusive sheets. The origin of the garbenschiefer is less certain. Provisionally it is interpreted as a body of leucogabbroic affinity intruded into, or tectonically intercalated with, the supracrustal rocks of the belt.

Two supracrustal sequences are recognised: sequences A and B (figs $1 \& 2$ ). Because the broader lithological divisions are mappable throughout the belt, they are treated as formations in the sense of Gary et al. (1972).

\section{Sequence $A$}

Sequence $A$ comprises the amphibolite (lowest), lower banded iron, variegated schist, upper banded iron, calc-silicate, and felsic formations (fig. 2). Relict primary structures, predominantly graded layering in felsic detrital rocks, define the way up of the sequence. The lowest two formations are best developed to the west of lake $678 \mathrm{~m}$, but the upper formations are exposed throughout the belt.

Amphibolite formation. In the lower part of the amphibolite formation stripy diopsidehornblende-rich amphibolites are interbanded with grey, mesocratic, fine-grained laminated garnet- and clinopyroxene-bearing amphibolites with quartz lenticles, and a 2-3 m thick unit of laminated magnetite-amphibole-quartz rock. Upwards, the stripy diopside-hornblende-rich amphibolites are absent, and the formation is dominated by varieties of the laminated amphibolite.

Lower banded iron formation. This formation consists of laminated magnetite-quartz and amphibole-quartz rocks, locally with carbonate and possibly graphite. 


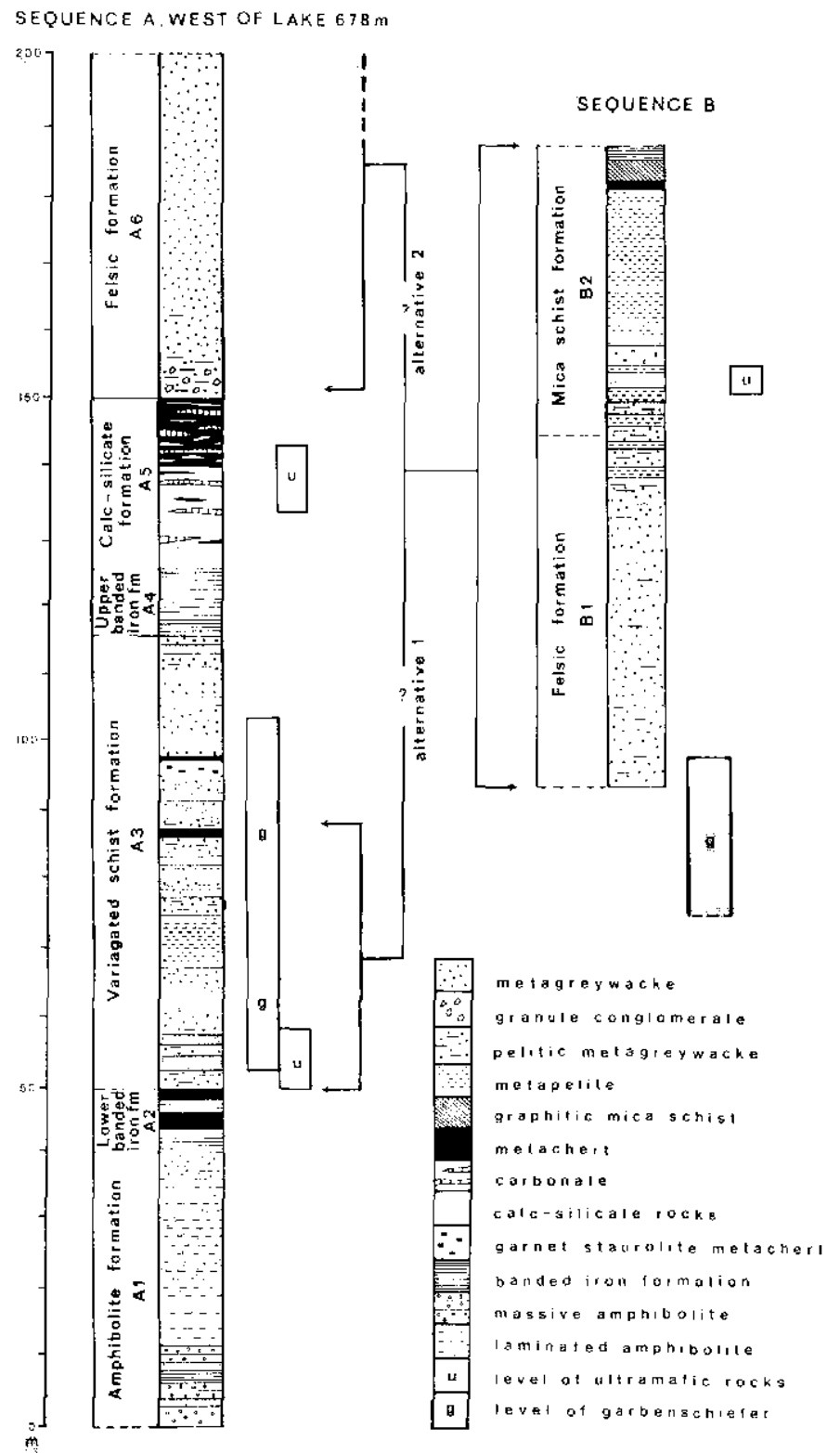

Fig. 2. Schematic stratigraphic columns of the Isua supracrustal belt (locations shown on fig. 1). The two alternative correlations between sequences $\mathrm{A}$ and $\mathrm{B}$ are indicated; the lower is preferred. 


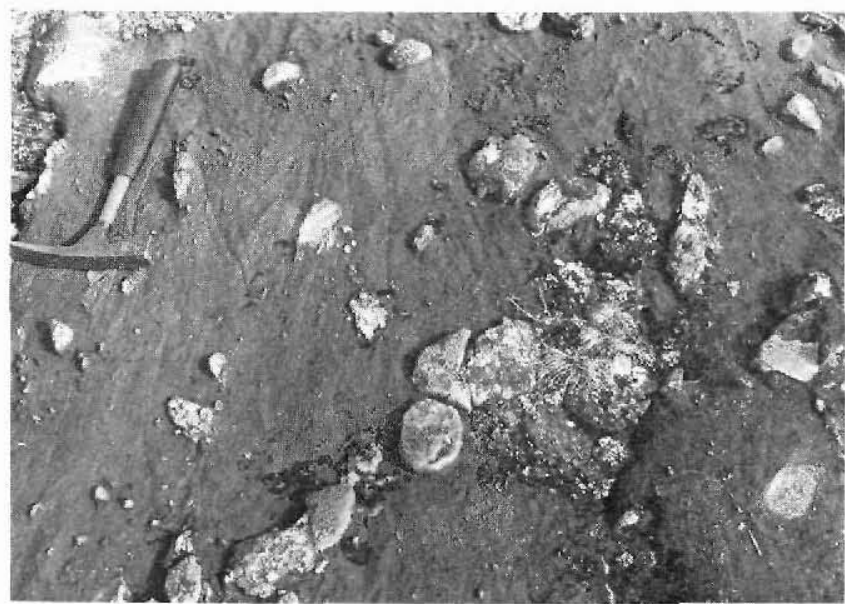

Fig. 3. $Y-Z$ section of acidic clasts in the 'conglomerate' unit, felsic formation, sequence $\mathrm{A}$.

Variegated schist formation. Predominant in this formation are banded plagioclase-garnetbiotite-amphibole rocks, which are interlayered with banded amphibolites, calc-silicate rocks and a unit of mica-garnet schist. The upper part of the formation contains a distinctive unit of, laterally variable, chlorite-garnet-biotite-staurolite-quartz schist (fig. 3).

Upper banded iron formation. This formation comprises quartz-magnetite, quartz-carbonate and quartz-amphibole units interlayered in no apparent order. In the eastern part of the belt there is within this formation a thin unit of garnet-mica schist which, where it reaches its maximum delvelopment, contains round nodules of quartz. The iron ore deposit and associated laminated metacherts at Isukasia are probably a lateral variant of this formation, greatly thickened by at least three phases of folding.

Calc-silicate formation. Irregularly-banded amphibole-rich rocks containing minor clinopyroxene, garnet and plagioclase are predominant in the lower part of this formation. These are interlayered with units of hornblende-plagioclase amphibolite. Lenses of buff-coloured (ankeritic?) carbonate and quartz are common. The upper part of the formation comprises quartz- and carbonate-rich rocks, there being an alternation of buff-coloured, calc-silicateand magnetite-banded carbonates and nodular metachert on a $5-100 \mathrm{~cm}$ scale. Extreme lateral variation of this unit is characteristic.

Felsic formation. The base of this formation comprises interlayered metagreywacke and granule conglomerate. The metagreywacke consists of altered plagioclase grains up to $5 \mathrm{~mm}$ in diameter set in a fine-grained feldspar-quartz-muscovite-biotite matrix. The granule conglomerate contains detrital plagioclase fragments (some multigranular) up to $2 \mathrm{~cm}$ in diameter set in a greywacke or semi-pelitic matrix. These rocks are locally carbonatised. The character of the upper parts of the felsic formation varies laterally. On the east shore of lake $678 \mathrm{~m}$ it contains nodules ranging from a few centimetres to over a metre in diameter (on $Z-Y$ surfaces). These nodules are fine-grained, foliated, acidic material with quartz and $\mathrm{K}$-feldspar, or $\mathrm{K}$-feldspar megacrysts replaced by muscovite in a matrix ranging from metagreywacke with small felsic fragments to carbonate or calc-silicate rich material (figs $3 \& 4$ ). Both matrix and nodules commonly have high contents of $\mathrm{K}_{2} \mathrm{O}$, located either in $\mathrm{K}$-feldspar or in muscovite. The origin of the nodules is controversial. In thin section the acidic nodules 
Fig. 4. $X-Y$ section of acidic clasts in the 'conglomerate' unit.

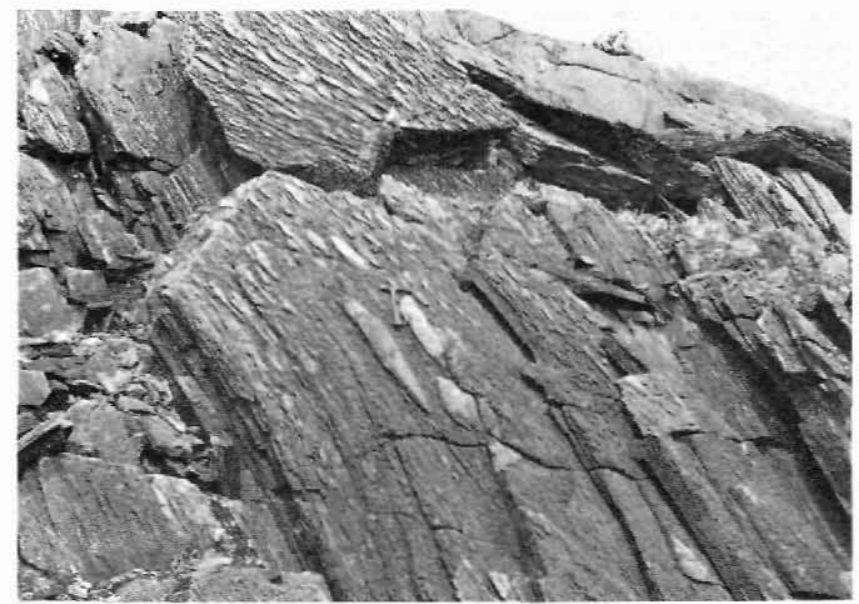

locally contain fiammé-like forms, suggesting that they were derived from felsic volcanic rocks (fig. 5). The nodules are nearly always matrix supported, and in some cases trains of nodules could have been derived from either an original more competent layer or from elongate larger nodules. E. D. interprets some of these structures as conglomerates, whereas A. P. N. and M. R. prefer to interpret them as layered rocks in which the competent units were disrupted more or less in situ by either sedimentary or subsequent tectonic processes. Eastwards and westwards these rocks grade into finer-grained, banded metagreywacke (similar to the lower part of the formation) with interlayers of mica schist.

Sequence A shows a change from basic volcanic activity and the formation of chemical sediments at the base to predominantly felsic, detrital sedimentation probably with acid volcanism at the top. The amphibolites at the base are similar to an abundant Akilia associa-

Fig. 5. Fiammé structures in acidic clasts, 'conglomerate' unit, felsic formation, sequence $\mathrm{A}$. The large quartz grains forming clear areas in the section are $3 \mathrm{~mm}$ in diameter.

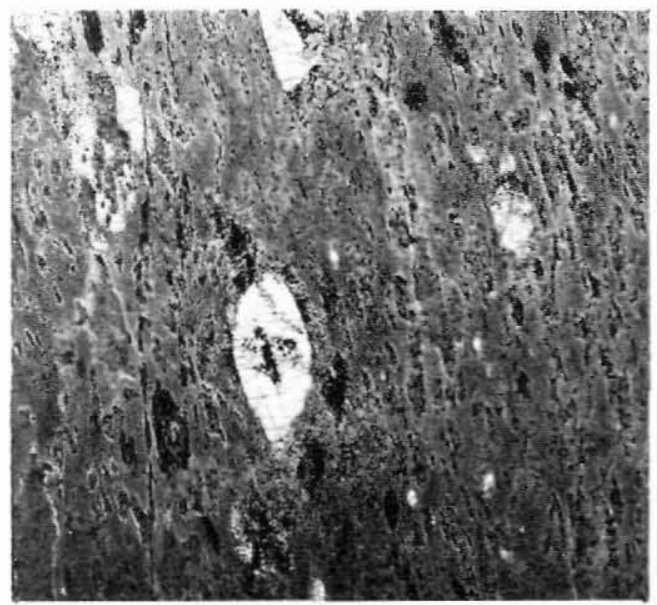


tion lithotype, which occurs as enclaves in the Amitsoq gneisses. These Akilia association amphibolites have geochemical affinities to some komatiites (McGregor \& Mason, 1977; Nutman, 1980).

\section{Sequence $B$}

Sequence $B$ consists of a felsic formation and a mica schist formation (figs $1 \& 2$ ). The boundary between the formations is somewhat arbitrary, being marked by a $30 \mathrm{~m}$ zone of interbedded, felsic, detrital sediments and mica schists. Relationships are complicated by the presence of sheared sheets of intrusive orthogneiss and small-scale isoclinal folding. The portrayal of the sequence in fig. 2 attempts to allow for folding, which may have doubled the original thickness. The way up of the sequence is based on a few facing determinations on graded bedding in the western margin base of the felsic formation. The lowest part of sequence $B$ is intruded by garbenschiefer, locally containing schlieren of banded amphibolite.

Felsic formation. Layered felsic rocks containing plagioclase, quartz, biotite and muscovite bedded on a scale of 2 to $10 \mathrm{~cm}$ are predominant in this formation. There are interbeds of garnetiferous biotite schist which increase in frequency upwards.

Mica schist formation. Most of this formation consists of chlorite-biotite-garnetquartz-staurolite schists with thin ferruginous quartz-rich interbeds, which are more frequent upwards. At the top of the formation the mica schists are graphitic and occur with a unit of banded iron formation.

The lithological changes in sequence B suggest a change from deposition of felsic, detrital sediments at the base, to pelites (derived possibly from weathered basic rocks) and finally at the top to chemical sediments.

\section{Relationship between sequences $A$ and $B$}

The relationship between the two sequences is uncertain. At the boundary between them rocks are schistose with considerable vein quartz and lithological units of sequence $A$ are either smeared out or truncated, suggesting the boundary is tectonic. If sequence B is stratigraphically below the parts of sequence A with which it is in tectonic contact, it could be a lateral variant of the variegated schist formation of sequence $A$ that is rich in felsic rocks and contains a unit of chlorite-biotite-garnet-quartz (-staurolite) schist with ferruginous metachert bands (fig. 2, alternative 1). Alternatively, if sequence B is from a stratigraphically higher level, the felsic formations of sequence A \& B could be broadly equivalent and the mica schist formation of sequence B would represent a higher stratigraphic level than is present in sequence A (fig. 2, alternative 2). Because of the relative positions of the garbenschiefer in the two sequences, the former alternative is preferred.

\section{Gneisses}

The region within the arcuate tract of the supracrustal belt (termed the central gneisses fig. 1) contains areas of low deformation in which original features of the gneiss complex are preserved. All the regional components of the central gneisses are cut by several sets of 
Fig. 6. Grey gneiss cut by dioritic dykes and migmatised by white gneiss sheets, northeast of lake 678 , Isukasia.

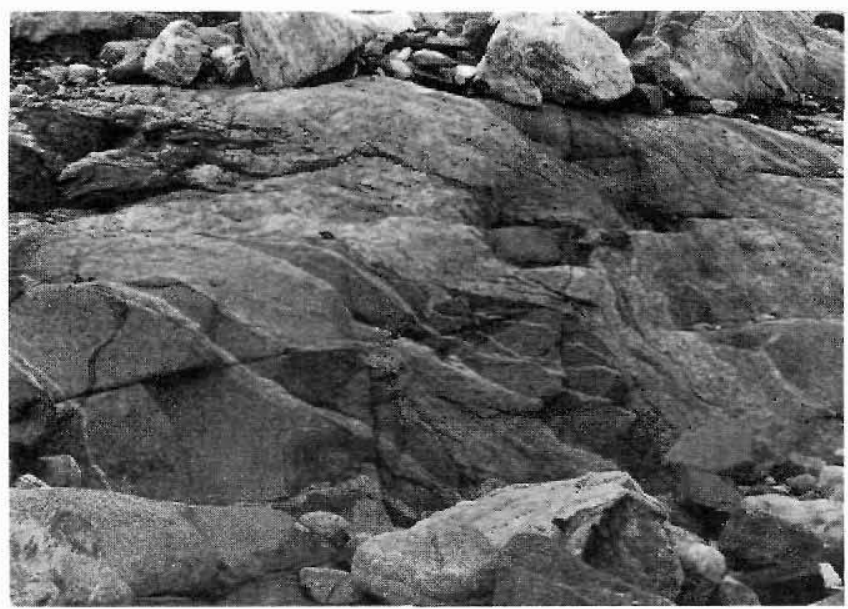

deformed major basic dykes (see later). The components of the gneiss complex pre-dating emplacement of the basic dykes are:

(I) Grey gneisses (oldest). These grey, weakly banded polyphase plagioclase-flecked tonalitic gneisses with sparse pegmatite banding form at least 60 per cent of the complex.

(II) Early grey sheets. Rare, thin, fine-grained tonalitic sheets cut the coarser-grained gneisses (I).

(III) Diorite dykes. The term Inaluk dyke is introduced for these diorite dykes. They are defined as diorite dykes that cut the early tonalites, but pre-date the granites of the central gneisses. They are melanocratic, biotite-bearing, and generally less than $2 \mathrm{~m}$ wide. They are not common, and their main concentration is in a north-south tract across the middle of the central gneisses.

(IV) White gneisses. These are granitic and pegmatitic, homogeneous to schlieric pale gneisses and make up a maximum of 40 per cent of the complex; they form swarms of sheets cutting lithologies I to III.

(V) Late grey sheets. Rare, thin homogeneous grey tonalitic sheets cut lithologies I to IV.

In areas of low strain the Inaluk dykes cut the grey gneisses vertically and the white gneiss sheets are moderately to gently inclined (fig. 6). The intrusion of closely-spaced white gneiss sheets may have caused metasomatism in thin screens of country rocks. This could be the reason for the high biotite content of the Inaluk dykes and some of the grey gneisses.

The white gneiss sheets are distributed throughout the complex and are normally less than $25 \mathrm{~m}$ thick. However, more massive units of white gneiss almost devoid of enclaves occur in the north.

Locally in the northern part of the central gneisses, the distinction between gneiss lithologies has been blurred. This change is accompanied by an increase in grain size in grey tonalitic rocks and also alteration of the basic dykes, particularly biotitisation along their margins. This suggests that these gneisses may have been locally recrystallised in a post-dyke 
metamorphic event which in the north of the central gneisses was not associated with significant deformation.

Towards the margin of the central gneisses and south of the Isua supracrustal belt, the gneisses were subjected to greater pre- and post-basic dyke strain. This transformed the migmatites into a banded grey and white gneiss in which the primary relationships between the phases have been obliterated. Such gneisses are similar in appearance to banded, multiphase Amîtsoq gneisses south of Godthåb, althoug the gneisses of the Isukasia area contain a higher proportion of pegmatitic and granitic material. Throughout the banded grey and white gneiss there are areas of lower deformation in which the same phases and relations observed in the central gneisses are recognised. Therefore, it is assumed that the same chronology can be applied throughout the area of gneisses investigated.

\section{Relationships between the Isua supracrustal belt and components of the gneiss complex}

Contacts between the grey gneisses and the supracrustal rocks are sharp. Gneiss contacts locally transgress layering in the supracrustal rocks. Early (pre-white-gneiss) fabrics in the grey gneisses are streaked-out parallel to the contacts. The general impression is that most grey gneiss-supracrustal belt contacts are (now) tectonic.

The southern part of the supracrustal belt on the west side of lake $678 \mathrm{~m}$ is heavily sheeted by grey gneiss. These grey gneiss sheets are sericitised and muscovite bearing, particularly towards their margins. The centres of the thicker sheets are locally better preserved, and texturally and geochemically they resemble the main phase grey gneisses (I), with which they are provisionally classified (see chemical analyses in Bridgwater et al., 1978). However, as discussed below the possibility remains that these gneiss sheets could belong to the thin grey gneiss sheets (II).

On the basis of the present evidence, there are several possible relationships between the supracrustal rocks and the main phase grey gneisses (I). Our favoured interpretation is that the grey gneiss sheets in the Isua supracrustal belt are part of the main phase grey gneisses (I), in agreement with the conclusion of Bridgwater \& McGregor (1974) that the gneisses are younger than, and intrude, the Isua supracrustal belt. However, if the grey gneisses intruding the supracrustal sequence are equivalent to the early thin grey sheets (II), then on the basis of field evidence the relative age of the main phase grey gneisses and the supracrustal sequence is not known, because all contacts between them are now tectonic. It is hoped that $\mathrm{Sm}-\mathrm{Nd}$ or $\mathrm{U}-\mathrm{Pb}$ isotopic studies and further field work will resolve this problem.

The white gneisses intrude along and migmatise earlier contacts between the supracrustal rocks and grey gneisses, and also occur sporadically as intrusive sheets within the supracrustal belt. Some contacts between the supracrustal belt and the gneisses are wholely tectonic, banded grey and white gneiss being juxtaposed with sheared supracrustal lithologies.

Enclaves of supracrustal rocks in the central gneisses are rare. They mainly occur in arcuate tracts less than $200 \mathrm{~m}$ wide and traceable over distances of up to $12 \mathrm{~km}$ (fig. 1). The commonest supracrustal rocks in these tracts are weakly-banded hornblendite/hornblendic amphibolite with relic clinopyroxene, laminated grey amphibolite and laminated quartzpyroxene-amphibole rocks. These lithologies are regarded as recrystallised equivalents of 
those that occur in the lowest exposed stratigraphic level of the supracrustal belt, west of lake $678 \mathrm{~m}$. The supracrustal rocks of these tracts and the adjacent grey gneisses are extensively sheeted and agmatised by pegmatitic pale gneisses, the presumed equivalents of the regional white gneiss sheets. Where the supracrustal rocks in these tracts are in contact with grey gneisses the relationship between them is ambiguous. These tracts of supracrustal rocks may have been either tectonic slices in the grey gneisses, or strips spalled off from the main body of the supracrustal sequence during the sheeting-in of grey gneiss magmas, which were then selectively migmatised by white gneisses.

\section{Basic dykes}

The early Archaean rocks of the Isukasia area are cut by numerous, prominent basic dykes. Over much of the central gneisses the dykes are only slightly deformed and locally they retain their igneous textures and mineralogy. The dykes in the supracrustal belt and the adjacent gneisses are generally recrystallised into lineated hornblende-plagioclase amphibolites, and they are commonly folded or boudinaged, particularly where they cut carbonates and talc schists. Brief helicopter and boat reconnaissance work south of the supracrustal belt showed that southwards there is a general increase in the degree of post-dyke deformation, i.e. the degree to which the dykes are boudinaged, folded and rotated towards concordance with the compositional banding of the gneisses. At the most southerly place visited (latitude $65^{\circ} \mathrm{N}$ ) the dykes and gneisses are deformed and recrystallised to the extent that they bear more resemblance to the Ameralik dykes and Amitsoq gneisses of the Godthåb district than the dykes and gneisses of the central gneiss area.

On regional chronological grounds supported by chemical evidence the basic dykes of the Isukasia area have been correlated with part of the Ameralik dyke swarm outcropping in the Godthåb district (Gill \& Bridgwater, 1979). This interpretation is favoured by their change in appearance southwards as discussed above. Although it is likely that most of the dykes of the Isukasia area are Ameralik dykes, the correlation is not certain and they are not referred to as such in this paper. Instead we introduce the term Tarssartôq dykes (meaning 'hillside with dark lines' in Greenlandic) for the Archaean dykes of the Isukasia area. The Tarssartôq dykes are defined as the swarms of dykes that cut the central gneises and the supracrustal belt and which pre-date final ductile deformation and amphibolite facies metamorphism in the area. Tarssartôq dyke may be used for similar dykes to the south that can be traced either individually or as a member of a swarm northwards into the type area.

In the less deformed terrain of the central gneisses, several sets of Tarssartôq dykes are recognised; they are all progressively more deformed towards the south and west. The principal dyke swarms, in their sequence of instrusion, are:

(I) NNE-SSW trending ultramafic dykes. Where virtually undeformed, relic olivine and pyroxene may be present, but in their deformed state they are talcose schists. A podded, mafic dyke in the north, ternding $110^{\circ}$, is cut by dykes of sets II and III. However, its relationship with the ultramafic dykes is not observed.

(II) Arcuate sets of vertical or southerly dipping metadoleritic dykes, locally with plagioclase megacrysts. Many of these dykes intersect each other at angles of about $30^{\circ}$ 
where least-deformed, and may be parts of conjugate sets. Where deformed, the angle of intersection between the sets is reduced, and near to and within the supracrustal belt these dykes are locally podded and trend roughly concordant to the banding of the country rocks.

The largest members of these sets of dykes are coarse-grained and have characteristic reddish brown, crumbly weathering outcrops. They differ markedly from dykes previously examined chemically from the Isukasia area and could be regarded as a separate group. They are orthopyroxene bearing and show close geochemical and mineralogical affinities to the high $\mathrm{Mg}-\mathrm{Si}$ earliest members of the regional Proterozoic dyke swarm (Bridgwater et al., 1976) and to the late Archaean Ugpik metadolerite of the outer Godthåbsfjord area (Gill \& Bridgwater, 1979). These dykes appear to have crystallised from high $\mathrm{Mg} / \mathrm{low} \mathrm{Al}$ basic to intermediate magmas with affinities to recent boninites or komatiite basalts (Cameron et al., 1979). Their early position in the local Tarssartô dyke chronology and the fact that they are strongly deformed with pinch and swell structures in areas close to the contact with the supracrustal belt, where there are fresh undeformed Proterozoic dykes, precludes them from being members of the E-W trending earliest Proterozoic dyke swarm of the Fiskefjord area to the west (Berthelsen \& Bridgwater, 1960) which they resemble closely.

(III) N-S trending metadoleritic dykes, locally with plagioclase megacrysts. More than fifteen contacts are exposed of these dykes cutting dykes of set (II). The N-S dykes cut the deformed gneisses near the supracrustal belt at high angles of discordance and are superficially little-deformed. However, close inspection reveals that dykes within $2-3 \mathrm{~km}$ of the supracrustal belt have a well-developed, sub-vertical amphibole lineation and in some cases a faint $S$-fabric concordant to that in the host gneisses. Commonly, their trend changes abruptly across the inner edge of the supracrustal belt. This is considered to be due to both the original form of intrusion and subsequent deformation.

Away from areas of post-dyke strain and recrystallisation, dykes of all three categories frequently show primary textures ranging from the poikilitic plagioclases described from the high $\mathrm{Mg}$ dykes to more common ophitic and sub-ophitic textures, with primary plagioclase laths and, less commonly, clinopyroxenes preserved.

\section{Proterozoic dykes}

Several approximately N-S trending Mg-rich, Al-poor hypersthene-bearing dykes with poikilitic plagioclases cut the supracrustal rocks and the deformed Tarssartôq dykes. These young dykes are correlated with early members of the regional Proterozoic dyke swarms. They are locally sheared and dislocated along fault planes where they contain greenschist facies mineral assemblages comparable to that described from the Fiskefjord fault (Berthelsen \& Bridgwater, 1960).

\section{Tectonometamorphic history}

Several tectonometamorphic events are recognised. In an attempt to impose some uniformity on nomenclature, pre-Tarssartôq dyke events are described as D1a, D1b etc. This is then consistent with current usage of D1 for pre-Ameralik-dyke events in north-western Buksefjorden and adjacent areas south of Godthåb (Chadwick \& Nutman, 1979). 
Fig. 7. Cascading folds in a white gneiss sheet segmenting a screen of grey gneiss.

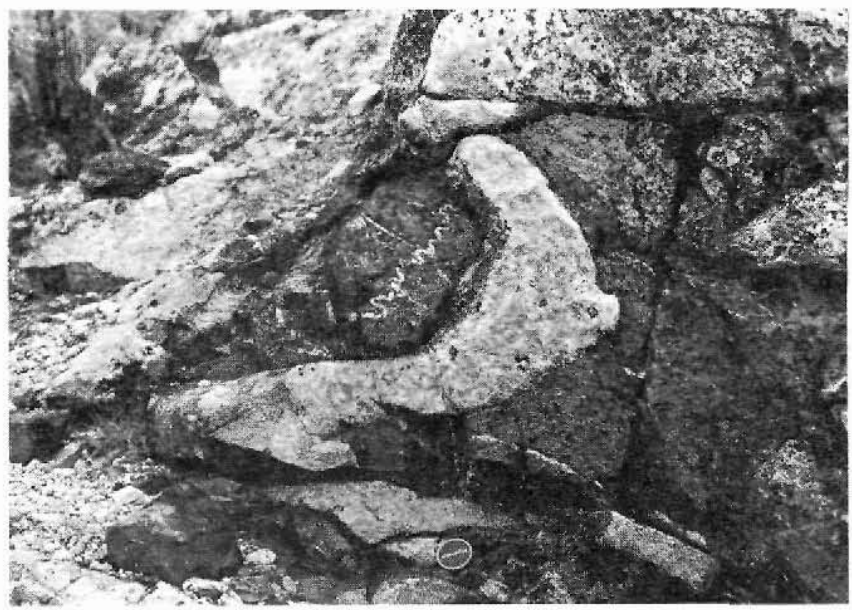

Isoclinal folds. The Isua supracrustal belt contains isoclinal folds (formed in event D1a) that are not apparent in the orthogneisses. Schistose fabrics in the supracrustals are intruded by grey gneiss sheets. Sedimentary facing directions, the sequence of lithologies and structural observations show that except in the north-east, sequence $\mathrm{A}$ is preserved in a D la isoclinal to tight synform, which follows the arcuate trend of the supracrustal belt (fig. 1). In the north-east there are further D1a isoclinal folds which appear to be deflected or truncated at the tectonic boundary with sequence $\mathrm{B}$, and have been refolded into basins and domes (fig. 1).

An axial surface foliation (S1a) is associated with D1a folds and dips vertically or steeply away from the central gneisses. This is coincident with compositional banding, except in fold hinges.

Mode of intrusion and degree of deformation of the gneisses. The areas of low-deformation within the central gneisses form a tectonically and magmatically sheeted complex, the elements of which are gently to moderately inclined. The orientations of these sheets have not been significantly disturbed by subsequent deformation. Although these rocks are relatively undeformed, there are zones of flattening concordant to the banding of the migmatites. The Inaluk dykes are commonly deformed into open, cascading 'concertina' folds, and are displaced laterally across white gneiss sheets. Thin white gneiss sheets that have broken up screens of grey gneiss are locally folded in the same pattern (fig. 7). Some enclaves of grey gneiss are boudin-shaped, and some thin screens of grey gneiss are podded (fig. 8). White gneiss sheets commonly have an internal fabric not seen in adjacent grey gneiss. These features suggest that intrusion of the white gneisses was syntectonic (event D1b), probably with components of horizontal translation and vertical compression. Some of the tectonic contacts between the main phase grey gneisses and the supracrustal belt are intruded by flaser-textured pegmatitic white gneiss and could have been formed during Dlb deformation.

Towards the supracrustal belt the central gneisses are more deformed, with rotation of the intrusive gneiss sheets so that they become sub-parallel to the steep foliation in the supra- 


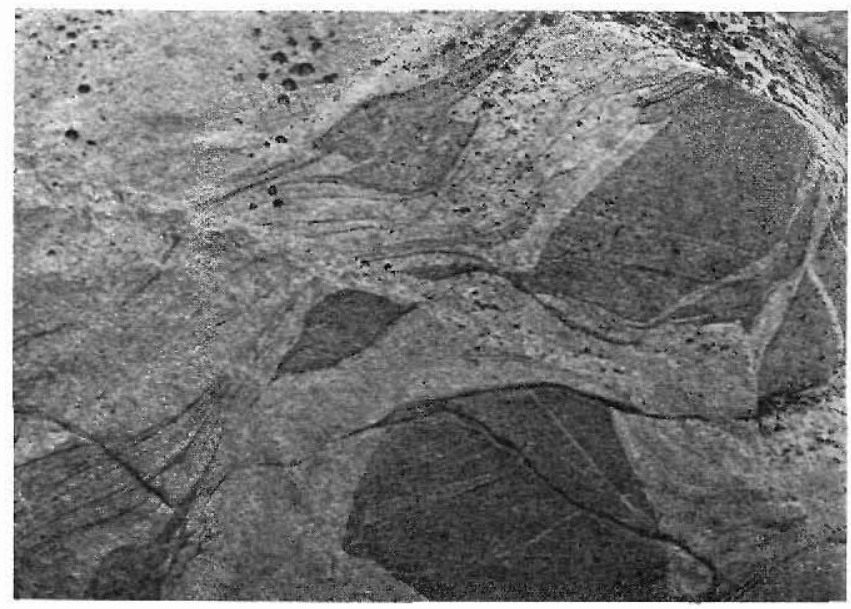

Fig. 8. Grey gneiss broken up into podded strips and isolated 'boudins' during emplacement of white gneiss sheets, northern central gneisses.

crustal rocks. Intrusive gneiss sheets in the supracrustal belt are highly deformed and follow the steeply-dipping S1a and compositional banding. White gneiss sheets cut small isoclinal structures in the supracrustal rocks, defining the younger limit of the period in which D1a occurred.

Steeply-plunging structures in the supracrustal belt. Folds with steeply plunging axes have been superimposed onto D1a structures. These are pre-Tarssartôq dyke folds (D1c) which are flattened, asymmetric and with amplitudes considerably greater than their wavelengths. Their fold axial traces lie at less than $30^{\circ}$ from the regional trend of lithological units, which in poorly exposed areas can give rise to a misleading impression of considerable small-scale tectonic imbrication within the supracrustal belt. The intensely lineated basin and dome structures in the north-eastern part of the supracrustal belt have been superimposed onto D1a isoclinal structures, but are dissected by relatively undeformed Tarssartôq dykes. These basins and domes possibly developed at the same time as Dic folds elsewhere in the supracrustal belt. There are also gentle post-Tarssartôq dyke folds, with small amplitudes relative to their wavelengths, except in tracts of intense deformation within units of calcareous rocks and some schists where the dykes are disrupted and isoclinally folded.

Development of a dome-like structure in the central gneisses. The foliation and compositional banding trends within the central gneisses define a non-cylindrical arcuate antiform (fig. 1). Relationships between the Tarssartôq dykes and the gneiss fabrics (fig. 1) suggest that an antiform was present before the intrusion of the Tarssartôq dykes (a large D1c structure?). After the emplacement of the dykes this antiform was accentuated and distorted into its present arcuate shape (fig. 1). This antiform was tightened on its limbs, with deformation of the Tarssartô dykes and further deformation of the gneisses and supracrustal rocks. This last event seems to have given rise to the mineral lineation in all the rocks near the margin of the central gneisses, including Tarssartô q dykes.

Interpretation of the major structural elements of the area. The central gneisses are structurally simple and form an irregular dome-like structure surrounded by the complexly deformed supracrustal belt. Superficially it appears that the supracrustal belt with its D1a 
folds could be a rimsyncline around a central gneiss dome. Several lines of evidence suggest that this is not the case, and that the isoclinal folds in the supracrustal belt formed before the development of the dome-like structure of the central gneisses:

(I) White gneiss sheets cut D1a folds in the supracrustal belt, but were deformed during events which gave rise to the dome-like structure.

(II) Where least deformed the central gneisses are seen to have originally been a complex of horizontally or gently dipping intersheeted gneisses, developed by syntectonic lateral intrusion of magmas.

(III) The dome-like structure is the product of at least two phases of deformation, which are separated in time by the intrusion of Tarssartôq dykes.

We suggest that the D1a folds were originally recumbent structures of nappe-like dimensions, formed during early tectonometamorphic events dominated by horizontal tectonics and injection of granitic rocks by lateral sheeting. During a series of subsequent events, giving rise to the dome-like structure of the central gneisses, the D1a folds were rotated and deformed so that their fold axial surfaces are now vertical or steeply-dipping.

\section{Metamorphism}

Deformed coarse-grained hornblende-plagioclase segragations occur in supracrustal amphibolite enclaves in the central gneisses and also locally in amphibolites within the supracrustal belt, but do not occur in the Tarssartôq dykes. They are interpreted as incipient partial melt sweats, suggesting that pre-Tarssartôq dyke metamorphism was at least middle amphibolite facies in the area. These conditions are in accord with temperatures of between 500 and $600^{\circ} \mathrm{C}$ at between 2-5 kb suggested by Boak \& Dymek (1980); Boak et al. (this report). This metamorphism is probably the result of high heat imput when either the grey or white gneisses were emplaced.

Where deformed, the Tarssartôq dykes are recrystallised into amphibolites which contain garnet locally. Some post-Tarssartôq dyke shear zones contain kyanite. Post-Tarssartôq dyke metamorphism attained amphibolite facies conditions, at least locally, although the effects are less apparent in the dykes cutting the central gneiss area. Subsequently there was patchy retrogression under greenschist conditions, notably along the western margin of the belt where retrogression may have been associated with shearing. The presence of mid-Proterozoic granite sheets (Kalsbeek et al., 1980) and Rb-Sr mineral ages of circa $1600 \mathrm{Ma}$ (Pankhurst et al., 1973) suggest that the area may have been affected by a significant Proterozoic metamorphic event.

\section{Discussion}

The relations observed in the field in 1980 are consistent with previous suggestions that the central gneisses of the Isukasia are younger than the supracrustal sequence, and that they may be correlated with the Amitsoq gneisses of the Godthåb area. Correlation of the later structural, metamorphic and magmatic history of the Isukasia area with that of the Godthåb area depends on the correlation between the majority of the basic dykes of the Isukasia area and the Ameralik dykes, since they provide the main control separating early Archaean 
from late Archaean events. Our preferred interpretation is that all the dykes which have been metamorphosed up to amphibolite facies grade or which have been strongly dislocated by post-dyke tectonic movements are equivalent to the Ameralik dykes and can be used to separate a metamorphic event at about $3600 \mathrm{Ma}$ (dated by regional $\mathrm{Rb}$-Sr whole-rock studies) from a younger tectonometamorphic event. This younger event has not been dated directly in the Isukasia area, but is provisionally correlated with the intrusion of the Nûk gneisses and subsequent metamorphism between 3100 and $2700 \mathrm{Ma}$ seen throughout the rest of the Archaean block. As the area is intruded by the regional swarms of mid-Proterozoic dykes we assume, in Table 1, that Proterozoic events are limited to faulting, local granite injection and recrystallisation of some units under greenschist facies conditions probably associated with a regional thermal event at $1600 \mathrm{Ma}$ (Pankhurst et al., 1973).

The present knowledge of the Isua supracrustal belt and adjacent gneisses, linked with the development of ideas of the Akilia association rocks and Amitsoq gneisses south of Godthåb (McGregor, 1973; McGregor \& Bridgwater, 1973; McGregor \& Mason, 1977; Nutman, 1980; Griffin et al., 1980;) provides a geological basis for models of crust formation and crustal processes in the early Archaean. Comparison between the two areas is particularly useful since the appear to represent different levels in the $c .3600$ Ma crust. Early Archaean rocks south of Godthåb were at a fairly deep level in the crust (at least $25 \mathrm{~km}$ ) at $3600 \mathrm{Ma}$ and were affected by granulite facies metamorphism. The Amîtsoq gneisses were relatively depleted in mobile components such as $\mathrm{Rb}$ and $\mathrm{U}$ at that time compared to the gneisses of the Isukasia area. The grey Amîtsoq gneisses south of Godthåb were intruded at about 3600 $\mathrm{Ma}$ by a suite of Fe-diorites and $\mathrm{Fe}$-granodiorites comparable to late or post-tectonic suites in the high grade areas of younger fold belts. Similar Fe-rich lithologies have not been found in the Isukasia area. In the high grade areas, the regional tonalitic grey Amîtsoq gneisses contain between 10 and 15 per cent of leucocratic veins and pegmatites. These are commonly less than one metre in width and do not form mappable units. In contrast the white gneisses of the Isukasia area form up to $\mathbf{4 0}$ per cent of the total gneiss outcrop and locally form massive bodies.

Tonalitic melts of similar composition to the grey gneisses have solidus-liquidus intervals lying in the range of 700 to $1100^{\circ} \mathrm{C}$ under crustal conditions (e.g. Wyllie, 1977). Thus, if the Isua supracrustal belt was a magmatic enclave in the grey gneisses, it would be expected that it would contain more evidence of metamorphic layering and incipient partial melting than it does. However, field evidence indicates that many grey gneiss supracrustal belt contacts are tectonic. This suggests that when these rocks were juxtaposed, the grey gneisses were sufficiently cool (thus probably below their solidus) to undergo brittle fracture. Elsewhere in the early Archaean of West Greenland, grey tonalitic gneisses clearly intrude supracrustal (Akilia association) rocks. On the other hand, the white gneisses are clearly intrusive into the supracrustal belt, and anastomose throughout grey gneisses as a complex of syn-tectonic gently-inclined sheets.

The Isua supracrustal sequence shows a general trend upwards from banded basic rocks with non-clastic, silica and carbonate-rich rocks to felsic detrital rocks. Field and unpublished geochemical data suggest that this records a change from the deposition of mainly basic volcanic sediments (tuffs - of broadly tholeiitic parentage?) and chemical sediments to the deposition of felsic detrital sediments derived, at least in part, from acid volcanics. On the other hand, the Akilia association and the lowermost part of the Isua supracrustal sequence are dominated by meta-igneous amphibolites with chemical sediments. Predominant within 
the meta-igneous amphibolites are stripy hornblende-diopside-rich varieties geochemically similar to some komatiites (McGregor \& Mason, 1977; Nutman, 1980).

We suggest that the Isua supracrustal and Akilia association rocks could be fragments from a thicker early Archaean supracrustal pile that was exploded into screens and enclaves by intercalation with, and by intrusion of, large volumes of tonalitic and granitic gneisses. Hence, the style of early Archaean crustal thickening resembles that of the late Archaean event in West Greenland, described by Bridgwater et al. (1974). In our present model, events between c. 3750 Ma and 3600-3500 Ma delimit a period of crustal thickening by tectonic and magmatic processes, perhaps in several distinct episodes.

We regard the published regional $\mathrm{Rb}-\mathrm{Sr}$ and $\mathrm{Pb}-\mathrm{Pb}$ ages as average values controlled by a variety of factors including original isotopic compositions, effects of metasomatic movement during crustal accretion and high grade metamorphism in the period c. 3750 to $3500 \mathrm{Ma}$ and partial redistribution of $\mathrm{Rb}, \mathrm{Sr}, \mathrm{U}$ and $\mathrm{Pb}$ during later events. We do not think that they necessarily offer immutable constraints on the age and crustal residence of individual units, and a programme of $\mathrm{U}-\mathrm{Pb}$ and $\mathrm{Sm}-\mathrm{Nd}$ studies is in progress using well-documented suites of separate phases from the gneiss complex subdivided both on field criteria and from restricted geographical areas.

Acknowledgements. This field programme is the result of plans made by a group of earth scientists who visited the Isua supracrustal belt in 1978 with the support of NATO research grant No. 949. Detailed mapping and stratigraphic studies on the supracrustal rocks were greatly helped by manuscript maps provided by J. H. Allaart. A. P. N. has been supported in Copenhagen by a fellowship from the Royal Society of London. E. D. was invited to go to Isukasia by P. Appel (Copenhagen University) and was financed by the Max Planck Institute for Cosmochemistry (Mainz) and by a US NSF grant to C. Ponnamperuma, University of Maryland.

\section{References}

Allaart, J. H. 1976: The pre-3760 my. old supracrustal rocks of the Isua area, central West Greenland, and the associated occurrence of quartz-banded ironstone. In Windley, B. F. (edit.) The Early History of the Earth, 177-189. London: Wiley.

Baadsgaard, H. 1976: Further U-Pb dates on zircons from the early Precambrian rocks of the Godthåbsfjord area, W. Greenland. Earth planet. Sci. Lett. 33, 261-267.

Berthelsen, A. \& Bridgwater, D. 1960: On the field occurrence and petrography of some basic dykes of supposed pre-Cambrian age. From the southern Sukkertoppen district, western Greenland. Bull. Grønlands geol. Unders. 24, (also Meddr Grønland 123,3) 43 pp.

Boak, J. L. \& Dymek, R. F. 1980: An occurrence of kyanite at Isua, West Greenland and implications for early Archaean geothermal gradients. Abstr. Geol. Soc. Am. 12, 389 only.

Boak, J. L., Dymek, R. F. \& Gromet, L. P. 1983: Petrology and rare earth element geochemistry of clastic metasedimentary rocks from the Isua supracrustal belt, West Greenland. Rapp. Grønlands geol. Unders. 112, 23-33.

Bridgwater, D. \& McGregor, V. R. 1974: Field work on the very early Precambrian rocks of the Isua area, southern West Greenland. Rapp. Grønlands geol. Unders. 65, 49-53.

Bridgwater, D., McGregor, V. R. \& Myers, J. S. 1974: A horizontal tectonic regime in the Archaean of Greenland and its implications for early crustal thickening. Precambrian Res. 1, 179-197. 
Bridgwater, D., Keto, L., McGregor, V. R. \& Myers, J. S. 1976: Archaean gneiss complex of Greenland. In Escher, A. \& Watt, W. S. (edit.) Geology of Greenland, 18-75. Copenhagen: Geol. Surv. Greenland.

Bridgwater, D., Collerson, K. D. \& Myers, J. 1978: The development of the Archaean gneiss complex of the North Atlantic region. In Tarling, D. H. (edit.) Evolution of the Earth's Crust, 123-146. London: Academic Press.

Bridgwater, D., Allaart, J. H., Baadsgaard, H., Collerson, K. D., Ermanovics, I., Gorman, B. E., Griffin, W., Hanson, G., McGregor, V. R., Moorbath, S., Nutman, A. P., Taylor, P., Tveten, E. \& Watson, J. 1979: International fieldwork on Archaean gneisses in the Godthåbsfjord-Isua area, southern West Greenland. Rapp. Grønlands geol. Unders. 95, 66-71.

Cameron, W. E., Nisbet, E. G. \& Dietrich, V. I., 1979: Boninites, komatiites and ophiolitic basalts. Nature, Lond. 280, 550-553.

Chadwick, B. \& Nutman, A. P. 1979: The Archaean structural evolution in the northwest of the Buksefjorden region, southern West Greenland. Precambrian Res. 9, 199-226.

Gary, M., McAfee, R. \& Wolf, C. L. 1972: Glossary of Geology. Washington D. C.: American Geological Institute.

Gill, R. C. O. \& Bridgwater, D. 1979: Early Archaean basic magmatism in West Greenland: the geochemistry of the Ameralik dykes. J. Petrol. 20, 695-726.

Griffin, W. L., McGregor, V. R., Nutman, A.P., Taylor, P. N. \& Bridgwater, D. 1980: Early Archaean granulite facies metamorphism south of Ameralik, West Greenland. Earth planet. Sci. Lett. 50, $59-74$.

Hamilton, P. J., O'Nions, R. K., Evensen, N. H., Bridgwater, D. \& Allaart J. H. 1978: Sm-Nd isotope investigations of the Isua supracrustals and implications for mantle evolution. Nature 272, 41-43.

Kalsbeek, F., Bridgwater, D. \& Boak, J. 1980: Evidence of mid-Proterozoic granite formation in the Isua area. Rapp. Grønlands geol. Unders. 100, 73-75.

McGregor, V. R. 1973: The early Precambrian gneisses of the Godthåb district, West Greenland. Phil. Trans. R. Soc. Lond. A 273, 343-358.

McGregor, V. R. and Bridgwater, D. 1973: Field mapping of the Precambrian basement in the Godthåbsfjord district, southern West Greenland. Rapp. Grønlands geol. Unders. 55, 29-32.

McGregor, V. R. \& Mason, B. 1977: Petrogenesis and geochemistry of metabasaltic and metasedimentary enclaves in the Amîtsoq gneisses, West Greenland. Am. Miner. 62, 887-904.

Moorbath, S., O'Nions, R. K. \& Pankhurst, R. J. 1975: The evolution of Early Precambrian crustal rocks at Isua, West Greenland - geochemical and isotopic evidence. Earth. planet. Sci. Lett. 27, 229-239.

Moorbath, S., Allaart, J. H., Bridgwater, D. \& McGregor, V. R. 1977: Rb-Sr ages of very early Archaean supracrustal rocks and Amîtsoq gneisses at Isua. Nature 270, 43-45.

Nutman, A. P. 1980: A field and laboratory study of the early Archaean rocks of the northwestern Buksefjorden region, southern West Greenland. Unpublished Ph.D. thesis. Univ. Exeter.

Pankhurst, R. J., Moorbath, S., Rex, D. C. \& Turner, G. 1973: Mineral age patterns in c. 3700 my old rocks from West Greenland. Earth planet. Sci. Lett. 20, 157-170.

Wyllie, P. J. 1977: Crustal anatexis: an experimental review. Tectonophysics 43, 41-71.

D.B. \& M.R.,

Geologisk Museum,

$\emptyset$ ster Voldgade 5-7, 1350 Copenhagen $K$.
E.D.,

Department of Geological Sciences,

Harvard University,

Cambridge, Massachusetts 02138,

USA.
R.C.O.G.,

Department of Geology and Mineralogy, Oxford University, Oxford OXI 3PR,

U.K. 